\title{
PENINGKATAN KETRAMPILAN BERBICARA (SPEAKING) MAHASISWA MELALUI TEKNIK ENGLISH DEBATE
}

\author{
Atik Rokhayani \\ Agung Dwi Nur Cahyo \\ e-mail: atik.rokhayani@umk.ac.id
}

Universitas Muria Kudus

\begin{abstract}
There are many teaching techniques used by the English teachers/lecturers to improve English skills especially speaking. Speaking is considered as the most difficult skill since in Indonesia English plays as an international language. For that reason, the lecturers have to select the appropriate teaching techniques in order to gain the students' attention and motivation. One of the techniques is English Debate. The objective of this study is to know whether English Debate can improve the students' speaking skill. This study belongs to classroom action research which is applied for the ESA (English Students Association) of the fourth semester students of English Education Department of Muria Kudus University in the academic year 2014/2015. In the class, the students are taught by using English Debate technique. The result of this study shows that the students' mean score of cycle 1 is 69.28 and it can be categorized into sufficient. Then the writers continued to cycle 2. The result of the students' mean score of speaking ability is 80.14 and it can be categorized into good. It can be concluded that English Debate technique can be used by the English teachers/lecturers in the English class to improve students speaking skill. In the English Debate, there is a topic that force the debaters to speak in English. In addition, English Debate technique can also be used to improve students' vocabulary.
\end{abstract}

Keyword: Speaking, English Debate

\begin{abstract}
ABSTRAK
Ada beberapa teknik pembelajaranyang dapat digunakan oleh guru/dosen Bahasa Inggris untuk meningkatkan kemampuan Bahasa Inggris terutama berbicara (speaking).Speaking dianggap sebagai kemampuan yang paling sulit karena di Indonesia Bahasa Inggris merupakan bahasa internasional. Berdasarkan alas an tersebut, dosen harus memilih teknik pembelajaran yang tepat untuk meningkatkan perhatian dan motivasi mahasiswa. Salah satu teknik pengajaran tersebut adalah teknik English Debate. Tujuan dari penelitian ini adalah untuk mengetahui apakah teknik English Debate dapat meningkatkan kemampuan speaking mahasiswa. Penelitian ini merupakan Penelitian Tindakan Kelas yang diterapkan terhadap mahasiswa ESA (English Students Assiciation) semester 4 Pendidian Bahasa Inggris Universitas Muria Kudus tahun akademik 2014/2015. Selamaa proses pembelajaran, mahasiswa diajar dengan menggunakan teknik English Debate. Hasil penelitian menunjukkan bahwa nilai rata-ratanya mahasiswa si siklus 1 adalah 69,28 dan dapat dikategorikan menjadi cukup. Kemudian peneliti melanjutkan ke siklus 2. Hasil nilai rata-rata nilaispeaking mahasiswa adalah 80,14 dan dapat di kategorikan menjadi baik. Berdasarkan data
\end{abstract}


diatas dapat disimpulkan bahwa teknik English Debate dapat digunakan bagi guru/dosen Bahasa Inggris untuk meningkatkan meningkatkan kemampuan/speaking mahasiswa. Di dalam teknik Englsh Debate ada topic yang mengharuskan bagi peserta debat untuk berbicara bahasa Inggris. Disamping itu, teknik English Debate juga dapat digunakan untuk meningkatkan kosakata mahasiswa.

\section{Kata Kunci: Speaking, English Debate}

\section{PENDAHULUAN}

Di Indonesia, Bahasa Inggris diajarkan dari tingkat pendidikan terendah sampai tertinggi. Di tingkat Perguruan Tinggi, Bahasa Inggris merupakan salah satu mata kuliah wajib yang harus ditempuh oleh mahasiswa semua jurusan.Hal ini menjadikan Bahasa Inggris sebagai bahasa asing yang di pelajari oleh banyak orang terutama akademisi.Idealnya Bahasa Inggris harus digunakan sebagai alat komunikasi bukan dijadikan sebagai mata pelajaran atau mata kuliah saja.Oleh karena itu empat kemampuan yaitu Listening, Reading, Speaking dan Writing harus di kuasai semua oleh pengguna bahasa yang tidak dapat dipisahkan satu dengan yang lainnya.Di samping itu elemen-elemen bahasa Inggris (Vocabulary, Grammar dan Pronunciation juga harus dikuasai guna mendukung pemerolehan bahasa Inggris yang seutuhnya.

Perguruan Tinggi merupakan agent of change (agen perubahan) bagi masyarakat Indonesia untuk menjadi warga yang lebih berpendidikan atau bermartabat.Sehingga peran Perguruan Tinggi sangat diperlukan adanya.Universitas Muria Kudus merupakan salah satu perguruan tinggi yang sedang berkembang yang berlokasi di Kudus.Ada beberapa Program Studi yang di tawarkan dengan berbagai disiplin ilmu yang berbeda.Diantaranya yang banyak diminati adalah Pendidikan Bahasa Inggris. Pendidikan Bahasa Inggris akan menciptakan Sarjana Pendidikan yang mampu bersaing di dunia pasar dan mampu mengembangkan ilmunya yaitu Pendidikan Bahasa Inggris untuk diamalkan kepada masyarakat. Mahasiswa lulusan Pendidikan Bahasa Inggris juga harus dapat berkomunikasi lancar menggunakan Bahasa Inggris.

Dewasa ini, penerapan model pembelajaran kooperatif harus ditekankan oleh tenaga pengajar atau dosen di Perguruan Tinggi yang lebih memfokuskan pada Student Centre Learning. Namun hal ini mengurangi peran aktif dosen dalam proses belajar mengajar. Dosen merupakan fasilitator yang mengatur jalannya kegiatan di kelas dengan tidak mengurangi keaktifan yang harus di lakukan oleh mahasiswa.Namun peran dosen di sini tidak sebagai seorang diktator yang bisa memaksakan kehendaknya dalam mengajar.Dosen harus bisa menciptakan suasana kondusif di dalam kelas.Jadi teknik pembelajaran harus di sesuaikan dengan karakteristik mahasiswa.

Proses pembelajaran di kelas juga sangat mempengaruhi suksesnya pendidikan. Sehingga profesionalisme dosen sangat dituntut keberadaannya.Ada beberapa teknik yang dapat diterapkan dalam pembelajaran Bahasa Inggris.Namun terknik tersebut juga harus disesuaikan dengan English skills (kemampuan Bahasa Inggris) maupun English components (komponen Bahasa Inggris). Dalam penelitian ini, peneliti memfokuskan pada pengajaran 
Speaking(berbicara) bagi mahasiswa. Penelitian ini menggunakan teknik English Debate untuk meningkatkan Speaking mahasiswa.

Banyak mahasiswa beranggapan bahwa Speakingmerupakan salah satukemampuan yang sulit dilakukan mengingat bahwa masyarakat Indonesia tidak menggunakan Bahasa Inggris sebagai bahasa sehari-hari. Dalam pembelajaran, dosen harus menggunakan teknik yang menyenangkan dan tidak membosankan bagi mahasiswanya. English Debate merupakan salah satu teknik yang dapat digunakan untuk meningkatkan Speaking mahasiswa karena dalam teknik ini mahasiswa akan mendapatkan topic yang harus diperdebatkan oleh dua tim. Tiap tim terdiri dari tiga anggota. Jadi masing-masing anggota harus menyampaikan ide atau opini terhadap tim lawan dengan menggunakan Bahasa Inggris. Oleh karena itu, para pakar Bahasa Inggris menganggap English Debate sangat efektif apabila diterapkan untuk meningkatkan Speaking.

Berdasarkan ilustrasi di atas, peneliti ingin memberikan solusi terhadap pembelajaran bahasa Inggris dengan menggunakan English Debate sebagai teknik untuk meningkatkan Speaking mahasiswa.

\section{LANDASAN TEORI}

\section{Speaking}

Speaking merupakan ketrampilan berbahasa lisan yang fungsional dalam kehidupan manusia sehari-hari.Betapa tidak karena dengan berbicara kita dapat memperoleh dan menyampaikan informasi.Namun bagi warga Indonesia, berbicara bahasa Inggris lancar merupakan tantangan berat karena kita tidak menggunakan Bahasa Inggris sebagai bahasa komunikasi sehari-hari.

Speaking adalah kemampuan yang produktif.Speaking tidak dapat dipisahkan dari listening (mendengarkan).Ketika kita berbicara, maka kita menciptakan sebuah teks yang bermakna.Didalam komunikasi, kita dapat menemukan pembicara, pendengar maupun pesan dan feedback (umpan balik). Disamping itu Speakingtidak dapat dipisahkan juga dengan pronunciation (pelafalan).

Melatih dan meningkatkan English skills bagi mahasiswa dalam berbahasa lisan merupakan salah satu tugas dosen yang tidak ringan. Dosen yang berpengalaman dan kreatif rasanya tidak akan mengalami kesulitan dalam memilih strategi yang tepat untuk memilih tugas itu.

Menurut Ladouse (pada Nunan, 1991: 23) speaking merupakan suatu aktifitas untuk menjelaskan seseorang pada situasi tertentu ataupun aktifitas untuk melaporkan sesuatu. Sedangkan menurut Tarigan (1990: 8) "Berbicara adalah cara untuk berkomunikasi yang berpengaruh hidup kita sehari-hari”. Hal ini berarti speaking merupakan suatu cara berkomunikasi yang dapat mempengaruhi kehidupan seseorang.

Berdasarkan penjelasan diatas, penulis menyimpulkan bahwa speaking merupakan cara untuk menyatakan apa yang kita rasakan yang kemudian diwujudkan dalam bentuk proses bahasa lisan antara dua orang atau lebih.

\section{Teknik Pengajaran Bahasa Inggris}

Teknik adalah cara konkrit yang dipakai saat proses pembelajaran berlangsung (Sugandi: 2004:15). Dalam hal ini tenaga pengajar dapat menggunakan teknik yang berbeda mestipun metode yang digunakan sama. 
Teknik pengajaran Speaking terhadap mahasiswa harus menggunakan teknik yang menyenangkan dan tidak membosankan. Banyak orang beranggapan bahwa pembelajaran Speaking itu rumit dan butuh keberanian mahasiswa untuk memproduksi ucapan. Inilah yang sering ditakutkan para tenaga pengajar.

Sebagian besar orang mengira Speaking itu butuh waktu lama dan sulit bagi mahasiswa untuk mengadaptasinya. Ada beberapa teknik yang dapat diterapkan dalam pembelajaran Bahasa Inggris. Dengan adanya teknik yang tepat para dosen di Perguruan Tinggi tidak akan lagi menganggap bahwa Speaking bagi mahasiswa itu sulit dan bisa diminimalisasi. Teknik-teknik yang dimaksud adalah:

1. Ask and Answer

Mahasiswa diminta melakukan tanya jawab. Prosesnya, mintalah mahasiswa mencatat beberapa pertanyaan interview kalau perlu dihafalkan.Kemudian bebaskan mahasiswa bertanya kepada teman di kelasnya.Sesuaikan pertanyaan dengan tema. Untuk mengecek apakah mahasiswa melakukan tugas tersebut, mintalah mereka membuat catatan yang harus dilaporkan kepada dosen setelah proses pembelajaran berakhir. Dosen hanya memonitor mahasiswa dan memberikan waktu untuk mahasiswa melakukan tanya jawab.

2. Describe and Draw

Mahasiswa dibuat berpasangan.Mahasiswa A mempunyai gambar yang tak diketahui oleh mahasiswa B, begitu pula sebaliknya. Mahasiswa A menerangkan gambar yang ia punyai dan mahasiswa B menggambar sesuai keterangan siswa A. Setelah siswa A selesai, ganti mahasiswa B menerangkan gambarnya. Mintalah mereka membandingkan gambarnya dan memberi nilai sesuai selera mereka.

\section{Discussion}

Tentukan sebuah topik dan mintalah mahasiswa secara berkelompok mendiskusikan topik sesuai gambar. Tehnik ini cocok diterapkan bagi intermediate dan advance learners.

\section{Guessing}

Dosen atau beberapa mahasiswa mempunyai sebuah informasi yang harus ditebak oleh mahasiswa atau kelompok lain dengan menanyakan dalam Bahasa Inggris.

5. Remembering

Siswa menutup mata dan mengingat gambar misalnya benda di dalam kelas atau letak tempat-tempat.Tehnik ini efektif untuk mengasah daya ingat dan meminimalisir lupa terhadap kosakata.

\section{Role Play}

Teknik ini cocok untuk pembelajar yang telah mencapai level intermediate dan di atasnya. Mahasiswa mempraktekkan sebuah situasi semisal di kantor polisi, pengadilan, drama, dan lain-lain. Mahasiswa hanya diminta menggunakan ungkapan-ungkapan yang pernah dipelajari atau menggunakan bantuan kartu.Pada kondisi ini, dosen bertindak memberi arahan dan memonitoring kegiatan.

7. English Debate

English Debat sangat tepat apabila digunakan untuk meningkatkan kemampuan berbahasa Inggris mahasiswa. Teknik ini tidak tepat apabila 
diterapkan pada pengajaran Bahasa Inggris young learners (anak-anak) karena teknik ini membutuhkan vocabulary yang banyak dan keberanian dari para mahasiswa yang akan berdebat.

\section{Teknik English Debate}

English Debate merupakan salah satu teknik pembelajaran Bahasa Inggris yang sangat penting yang dapat digunakan untuk meningkatkan kemampuan akademik mahasiswa. Penelitian ini lebih memfokuskan pada Speaking.Tenaga pengajar/dosen di Perguruan Tinggi harus memilih materi untuk dijadikan topic motion bagi tim yang akan berdebat. Ada dua tim yang akan berdebat yang disebut tim pro dan kontra. Mahasiswa di bagi kedalam beberapa kelompok.Didalam kelompoknya, siswa (posisi pro dan lainnya dalam posisi kontra) melakukan perdebatan tentang topik yang ditugaskan. Dosen harus selalu memantau kegiatan debat yang dilakukan oleh mahasiswa.Selanjutnya dosen dapat mengevaluasi setiap mahasiswa tentang penguasaan materi yang meliputi kedua posisi tersebut dan mengevaluasi seberapa efektif mahasiswa terlibat dalam prosedur debat.

Pada dasarnya, agar semua model berhasil seperti yang diharapkan pembelajaran kooperatif, setiap model harus melibatkan materi ajar yang memungkinkan mahasiswa saling membantu dan mendukung ketika mereka belajar materi dan bekerja saling tergantung (interdependent) untuk menyelesaikan tugas.Ketrampilan sosial yang dibutuhkan dalam usaha berkolaborasi harus di pandang penting dalam keberhasilan menyelesaikan tugas kelompok. Ketrampilan ini dapat diajarkan kepada mahasiswa dan peran mahasiswa dapat ditentukan untuk memfasilitasi proses kelompok. Peran tersebut mungkin bermacam-macam menurut tugas, misalnya, peran pencatat (recoeder), pembuat kesimpulan (summarizer), pengatur materi (material manager), atau fasilitator dan peran dosen bisa sebagai pemonitor proses belajar ada dalam konsep atau pengertian belajar itu sendiri.

Dalam penelitian ini, penulis akan memberikan gambaran tentang format debat parlemen Australia yaitu :

1. Gambaran umum

1. Gambaran umum (Tim Afirmatif) mengajukan sebuah usulan kepada parlemen.

2. Pihak oposisi (Tim Negatif) menyanggah usulan tersebut.

3. Masing-masing pihak meyakinkan parlemen (Adjudicator)

4. Masing-masing mendapat alokasi waktu yang setara untuk mengemukakan pandangannya secara bergantian.

5. Pelaku

1. Tim Afirmatif beranggotakan 3 (tiga) orang

2. Tim negatif berangotakan 3 (tiga) orang

3. Tugas masing-masing tim

2. Adapun tugas dari masing-masing tim sebagai berikut:

a. $\varnothing$ Tim afirmatif

1. Mendefinisikan topik (motion) yang diajukan

2. Memberikan argumentasi yang mendukung

b. Ø Tim negatif 
1. Menyangga topik (motion) yang di definisikan oleh tim afirmatif

2. Membangun kasus yang melawan argumentasi tim afirmatif

3. Bila tim negatif memandang bahwa definisi yang diajukan oleh tim afirmatif tidak sah, tim negatif dapat menagajukan keberatan dan mengajukan definisi baru. Namun dalam hal ini tidak dapat dilakukan semata-mata karena tim negatif berpandangan bahwa defininya sendiri yang lebih tepat

\section{METODOLOGI PENELITIAN}

Dalam penelitian ini peneliti menggunakan metode Penelitian Tindakan kelas (PTK). Menurut Gregory, Kemmis, dan McTaggart (dalam Richard, 2000: 12) Penelitian Tindakan Kelas merupakan penelitian yang dilakukan untuk menginvestigasi apakah guru menggunakan metode pengajaran yang tepat dan dapat meningkatkan hasil belajar siswa. Sementara menurut Bogdan dan Biklen (dalam Burns, 1999: 30) PTK merupakan suatu rangkaian informasi yang sistematis yang dirancang untuk perubahan sosial.

Berikut tahapan-tahapan yang harus dilakukan peneliti untuk melaksanakan PTK:

1. Tahap perencanaan; yaitu proses pengembangan analisis secara kritis dari informasi yang diterima.

2. Tahap tindakan; proses pengambilan tindakan untuk mengimplementasikan perencanaan.

3. Tahap observasi; proses pengamatan terhadap dampak informasi secara kritis terhadap konteks target penelitian.

4. Tahap refleksi; proses perefleksian terhadap dampak yang terjadi pada masa yang akan datang.

\section{SUBJEK PENELITIAN}

Subjek dari penelitian ini adalah mahasiswa semester 4 Program Studi Pendidikan Bahasa Inggris, Fakultas Keguruan dan Ilmu Pendidikan, Universitas Muria Kudus. Peneliti memilih mahasiswa semester 4 karena mereka dianggap sudah mempunyai kemampuan dan pengetahuan Bahasa Inggris yang cukup.Peneliti memilih mahasiswa yang tergabung dalam ESA (English Student Association). Hal ini dilatarbelakangi karena mahasiswa ESA merupakan mahasiswa yang biasanya dipersiapkan untuk lomba debat berbahasa Inggris/English Debate Competition. Dengan adanya penelitian ini diharapkan kemampuan mereka semakin baik dalam hal Speakingyaitu dalam menyampaikan argument saat berdebat.

\section{HASIL PENELITIAN}

\section{Penerapan Teknik English Debate Untuk Meningkatkan Speaking Mahasiswa}

Penelitian ini bertujuan untuk menerapkan teknik English Debate untuk meningkatkan kemampuan berbicara/Speaking mahasiswa bagi semester 4 mahasiswa Pendidikan Bahasa Inggris Fakultas Keguruan dan Ilmu Pendidikan Universitas Muria Kudus. Sebelum melaksanakan siklus I, tim peneliti berdiskusi dengan mahasiswa untuk mendapatkan kebutuhan yang berkaitan dengan English Debate. Tim peneliti mengajak mahasiswa berdialog tentang topic-topik yang akan dijadikan tema/motion dalam berdebat. Dalam penelitian ini, tim peneliti 
memfokuskan pada pengajaran Speaking dengan menggunakan teknik English Debate. Jadi dalam mengukur hasil pembelajaran, peneliti menggunakan rubrik penilaian Speaking.

\section{Table 1.Indikator nilai Penilaian Speaking}

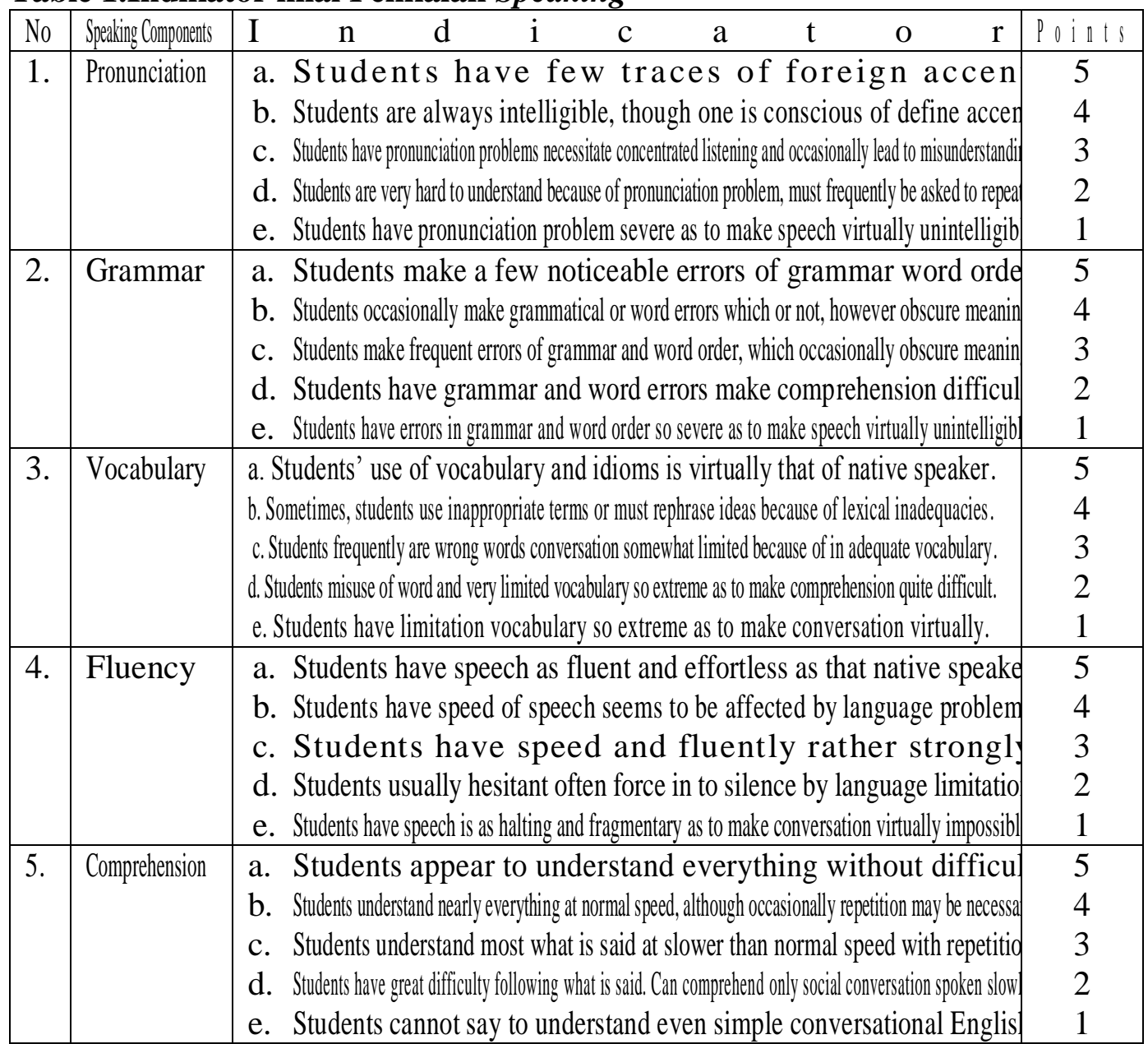

Berdasarkan rubric penilaian diatas, peneliti mengukur kemampuan Speakingmahasiswa ketika mereka melakukan debat bahasa Inggris. Untuk memudahkan penilaian, peneliti mengalikan empat tiap komponen sehingga nilai maksimal adalah 100. Sedangkan untuk mendeskripsikan nilai tersebut peneliti menggunakan kriteria penilaian sebagai berikut:

Tabel 2. Kriteria Penilaian Speaking

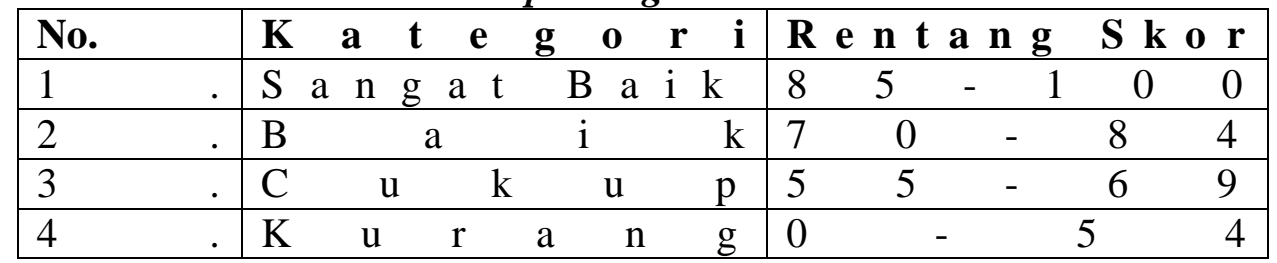

\section{Hasil Siklus I}

Penelitian ini merupakan Penelitian Tindakan Kelas di Pendidikan Bahasa Inggris Universitas Muria Kudus.Siklus I dilaksanakan pada tanggal 1 dan 15 April 2015.Kegiatan ini diikuti oleh 30 mahasiswa ESA semester 4. Dalam proses 
pembelajaran dosen menerapkan teknik English Debate. Selama proses pembelajaran mahasiswa mulai tertarik dengan teknik English Debate. Untuk mengukur Speaking mahasiswa, peneliti menggunakan rubric penilaian Speakingpada tabel 4.1. Hasil distribusi nilai hasil tes Speakingdapat di lihat di tabel berikut ini:

Tabel 3. Hasil Rekapitulasi Siklus I

\begin{tabular}{|c|c|c|c|c|c|c|c|c|c|c|}
\hline No & Kat e gor i & Rentang nilai & Frekuensi & \multicolumn{3}{|c|}{ Bobot Skor } & \multicolumn{4}{|c|}{ Persentase $(\%)$} \\
\hline 1 & Sangat baik & $85-100$ & 2 & 1 & 7 & 0 & 9 & & 8 & 2 \\
\hline 2 & $\begin{array}{llll}\text { B } & \text { a } & \text { i } & \text { k }\end{array}$ & $70-84$ & 9 & 6 & 3 & 2 & 3 & 6 & 4 & 8 \\
\hline 3 & $\mathrm{C} \quad \mathrm{u} \quad \mathrm{k} \quad \mathrm{u} \quad \mathrm{p}$ & $55-69$ & 1 & 9 & 3 & 0 & 5 & 3 & & 7 \\
\hline 4 & $\mathrm{~K}$ u $\mathrm{r}$ a $\mathrm{n} \mathrm{g}$ & $0-54$ & 0 & 0 & & & 0 & & & \\
\hline $\mathrm{J}$ & $\mathrm{m}$ & $\mathrm{a}$ & 2 & 17 & 3 & 2 & 1 & & ) & 0 \\
\hline $\mathrm{Ni}$ & a i rata - & $\mathrm{rata} \mathrm{skor}$ & $\frac{1732}{25}=$ & & & & & & & \\
\hline
\end{tabular}

Berdasarkan hasil siklus I, peneliti menemukan bahwa rata-rata nilai evaluasi tes Speakingdi siklus I adalah 69.28. Berdasarkan nilai rata-rata, hasil evaluasi siklus I mahasiswa dapat dikategorikan cukup.Peneliti masih menganggap bahwa nilai yang dicapai siswa belum maksimal.Dengan demikian peneliti melanjutkan kegiatan di siklus II karena siklus I perlu diperbaiki.

\section{Hasil Siklus II}

Siklus II dilaksanakan tanggal 27 April dan 4 Mei 2015..Kegiatan ini diikuti oleh 30 mahasiswa ESA semester 5 Pendidiakan Bahasa Inggris Universitas Muria Kudus. Dalam proses pembelajaran dosen menerapkan teknik English Debate dengan mengatur ulang posisi tempat duduk mahasiswa menjadi lebih bervariasi. Mahasiswa juga tidak hanya sebagai Debaters tetpi mereka juga berperan sebagai adjudicator, moderator dan time keeper. Selama proses pembelajaran di siklus II mahasiswa menjadi lebih antusias dalam mengutarakan ide/pendapat mereka. Di akhir siklus II peneliti menilai kemampuan Speakingmahasiswa ketika mereka berdebat. Adapun distribusi nilai hasil siklus II dapat di lihat pada tabel di bawah ini:

Tabel 4. Hasil Rekapitulasi Siklus II

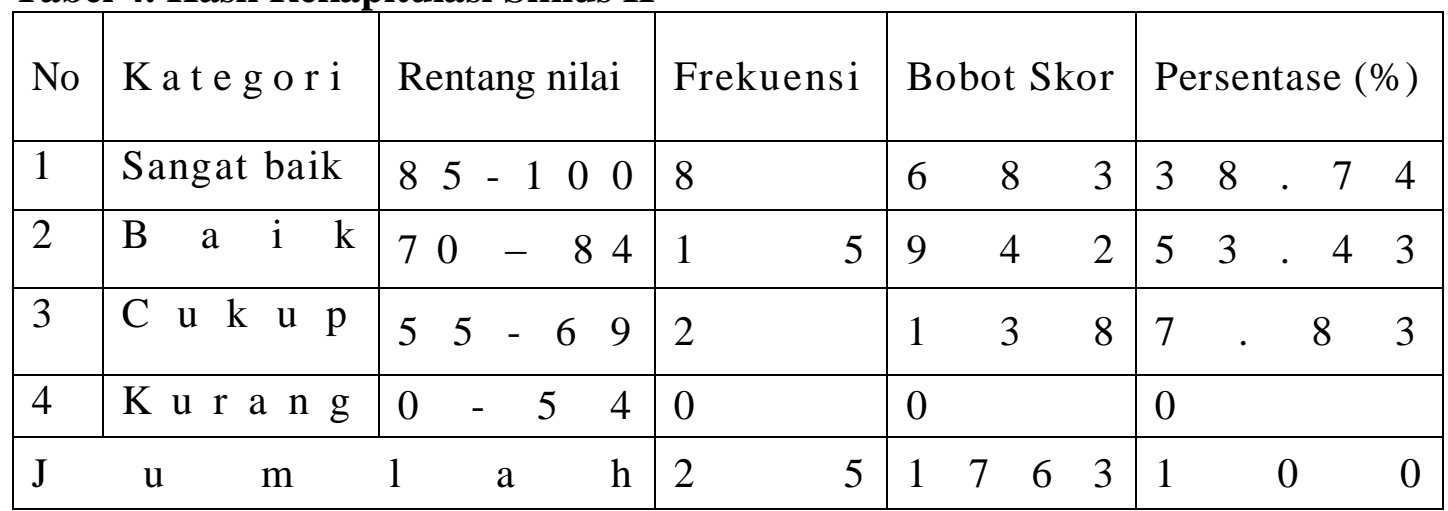




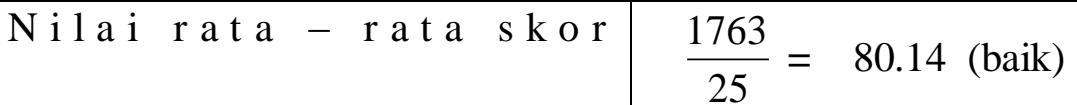

Berdasarkan nilai rata-rata, hasil evaluasi siklus II mahasiswa dapat dikategorikan baik.Peneliti menganggap bahwa nilai yang dicapai siswa sudah cukup baik.Dengan demikian peneliti tidak perlu lagi melaksanakan siklus III.

\section{Keefektifan Pembelajaran Dengan Teknik English Debate}

Catatan observasi yang telah dilakukan peneliti di setiap siklus penelitian, baik pada siklus I maupun siklus II, dapat menunjukkan bahwa English Debate efektif untuk diterapkan sebagai teknik pembelajaran Bahasa Inggris. Observasi peneliti mencakup proses pembelajaran dengan menerapkan English Debate melalui alur materi dan langkah-langkah pengajaran serta respon mahasiswa di tiap-tiap siklus. Berikut deskripsi hasil observasi peneliti dari dua siklus Penelitian Tindakan Kelas (PTK) yang telah dilakukan terhadap mahasiswa ESA Pendidikan Bahasa Inggris Universitas Muria Kudus.

\section{Observasi Siklus I}

Siklus I merupakan titik gerak penerapan English Debate sebagai teknik pembelajaran Bahasa Inggris.Untuk mempersiapkan pelaksanaan pembelajaran di siklus I, peneliti menyiapkan segala sesuatu untuk keperluan penelitian termasuk menyusun Lesson Plan.Tujuan dari penerapan Lesson Plan adalah untuk memberikan gambaran langkah-langkah tentang bagaimana penerapan teknik English Debate di dalam kelas untuk meningkatkan kemampuan berbicara/Speaking mahasiswa.Peneliti juga menyiapkan topic/motion. Adapun motion di siklus I ada 2 yaitu Advertising is harmful dan TV does more harm than good.

Pada tahap pelaksanaan, peneliti menerapkan teknik English Debate di kelas.Sebelum menerapkan teknik English Debate, peneliti yang merupakan dosen Pendidikan Bahasa Inggris menerangkan tentang English Debate.Penjelasan tentang English Debate meliputi jenis, hal-hal yang harus diperhatikan saat berdebat dalam Bahasa Inggris dan elemen-elemen yang ada dalam English Debate.Pada tahap ini peneliti membagi mahasiswa menjadi beberapa kelompok Debaters. Tiap 1 kelompok Debaters terdiri dari 3 mahasiswa yang berperan sebagai First Speaker, Second Speaker dan Third Speaker. Salah satu dari mereka juga harus ada yang menjadi Reply Speaker.

Di dalam kelas mahasiswa diperbolehkan membuka kamus dan menggunakan jaringan internet untuk mencari sumber materi dan topik debat. Dalam memberikan ide/gagasan topik yang disampaikan mahasiswa masih sangat kurang.Hal ini dikarenakan mereka tidak biasa menyampaikan ide saat berdebat.Beberapa dari mereka juga mengalamai kesulitan dalam mencari kosakata/diction yang menyebabkan terbatasnya penyampaian ide saat berdebat.

Pada tahap akhir penelitian di siklus I setelah semua mahasiswa melaksanakan debat Bahasa Inggris, peneliti membahas motion tersebut dan mengukur kemampuan Speaking mahasiswa. Dalam mengukur kemampuan Speaking mahasiswa, peneliti menggunakan rubrik penilaian Speaking yang meliputi pronunciation, grammar, vocabulary, comprehension dan fluency. Setelah itu peneliti mengklasifikasikan nilai yang diperoleh mahasiswa. Berdasarkan hasil pengukuran Speaking mahasiswa, peneliti mendapatkan nilai 
rata-rata yaitu 69,28 yang dikategorikan cukup. Oleh sebab itu peneliti memutuskan untuk melanjutkan ke siklus 2 untuk mendapatkan nilai yang lebih baik.

\section{Observasi Siklus II}

Tahap ini merupakan penyempurnaan yang dilihat dari hasil evaluasi siklus I. Pada siklus I, peneliti telah menjelaskan dan menerapkan teknik English Debate terhadap mahasiswa ESA semester 4 Pendidikan Bahasa Inggris Universitas Muria Kudus.Berdasarkan hasil evaluasi, peneliti mengharapkan hasil yang lebih signifikan untuk membuktikan bahwa teknik English Debat dapat digunakan untuk meningkatkan kemampuan berbicara/Speaking mahasiswa.Berikut adalah deskripsi hasil pengamatan di siklus II.

Siklus II merupakan siklus lanjutan dari siklus I. Di siklus II, peneliti masih menerapkan teknik English Debate terhadap mahasiswa ESA semester 4 Pendidikan Bahasa Inggris tahun akademik 2014/2015. Siklus II ini merupakan siklus penyempurnaan dari siklus I. Motion yang dipakai di siklus II adalah Education should be free, dan Internet is the best source in learning English. Peneliti memilih motion tersebut karena ada kaitannya dengan pendidikan dan akademik.Mahasiswa tampak lebih antusias dengan topik di siklus II ini.

Mahasiswa juga dibagi menjadi beberapa kelompok di siklus II ini. Sama halnya dengan siklus I peneliti membagi mahasiswa tiap 1 kelompok Debaters terdiri dari 3 mahasiswa yang berperan sebagai First Speaker, Second Speaker dan Third Speaker. Salah satu dari mereka juga harus ada yang menjadi Reply Speaker.Disamping itu mahasiswa juga berperan sebagai adjudicator, time keeper dan moderator. Hal ini bertujuan memberikan ilmu dan pengetahuan baru bagi mahasiswa untuk saling bertukar pengalaman.

Berdasarkan hasil penelitian di siklus II menunjukkan bahwa kemampuan mahasiswa ESA Pendidikan Bahasa Inggris Fakultas Keguruan dan Ilmu Pendidikan Universitas Muria Kudus baik. Hal ini tercermin dari penampilan English Debate yang mereka lakukan dan nilai rata-rata Speaking mahasiswa di siklus II 80,14 yang dikategorikan bagus. Ada 3 poin yang dianalisis peneliti yaitu matter, manner dan method.Dalam hal matter, mahasiswa masih belum maksimal dalam mengeksplorasi ide/gagasan yang disampaikan.Manner, mahasiswa mampu menggunakan eye contact, vocal, gesture dengan baik. Sedangkan Method, mahasiswa mampu mengatur waktu dan berperan sebagai Debaters dengan baik.

Secara keseluruhan penampilan mahasiswa di siklus II sudah baik dari sisi cara mereka berdebat dan Speaking mereka sehingga peneliti mengganggap sudah cukup baik dengan tidak melanjutkan lagi di siklus berikutnya. Dengan demikian penggunaan teknik English Debate dapat digunakan untuk meningkatkan kemampuan berbicara/Speaing mahasiswa.Namun teknik English Debate juga memiliki kelebihan dan kekurangan. Adapun kelebihan dan kekurangan dari teknik English Debate akan di bahas pada bagian selanjutnya.

\section{SIMPULAN}

Kesimpulan dari hasil penelitian tentang tindakan kelas menggunakan teknik English Debate terhadap mahasiswa ESA Pendidikan Bahasa Inggris Universitas Muria Kudus adalah sebagai berikut: 
Hasil dari penelitian ini menunjukkan adanya peningkatan kemampuan berbicara/Speaking mahasiswa dengan menggunakan teknik English Debate. Peningkatan ini dapat dilihat berdasarkan hasil nilai Speaking yang diberikan kepada mahasiswa yang meliputi hasil nilai siklus I dan siklus II. Hasil nilai pada siklus I menunjukkan nilai rata-rata kelas sebesar 69,28. Pada siklus II nilai ratarata kelas meningkat menjadi 80,14 , artinya terjadi peningkatan sebesar $10,86 \%$ dari siklus I ke siklus II. Peningkatan nilai rata-rata ini membuktikan keberhasilan peningkatan Speaking bahasa Inggris yang dimiliki mahasiswa.Keefektifan English Debate sebagai teknik pembelajaran dilihat dari hasil observasi pembelajaran. English Debate sangat tepat dan efektif digunakan sebagai teknik pembelajaran karena memberikan kesempataan bagi mahasiswa untuk mengekspresikan ide yang dimiliki ketika berdebat. Ini juga berdampak pada kemampuan Speaking mahasiswa dalam menyampaikan ungkapan-ungkapan bahasa Inggris menjadi lebih bagus.

Dilihat dari sisi kelebihan dan kekurangan English Debate sebagai teknik pembelajaran, maka dapat ditarik garis kesimpulan bahwa dengan berlatih English Debate mahasiswa dapat meningkatkan literasi dan kemampuan berargumen mereka. Mahasiswa juga juga dapat meningkatkan kemampuan public speaking. Sementara itu manajemen waktu yang lama dalam proses pembelajaran menjadikan kekurangan English Debate jika diterapkan dalam kelas yang mempunyai alokasi pembelajaran yang singkat/terbatas.

\section{DAFTAR PUSTAKA}

Alasmari, A and S. H. Ahmed. (2013). UsingDebate in EFL Classes. Canadian Center of Science and Education, 6 (1).

Arends, Richard I. 2008. Learning To Teach. Jogyakarta: Pustaka Pelajar.

Brown, Douglas. Prinsip Pembelajaran dan Pengajaran Bahasa. Jakarta: Pearson Education, Inc.

Harmer, J. 2007.The Practice of English Language Teaching (4 ${ }^{\text {th }}$ edition). Harlow: Pearson Education Limited.

Kathleen M. Bailey. (2005). Practical English Language Teaching: Speaking. New York: Mc Graw Hill.

McCarthy, Michael. 2008. Language Teaching: Vocabulary. China: Oxford University Press.

McNiff, Jean. 1992. Action Research: Principles and Practice. London: Routledge.

Nunan, David. 1991. Research Methods in Language Learning. Cambridge: Cambridge University Press. 
Swancik, Alan, Christoper Erskine and Ray D'cruz. (2003). The Australia-Asia Debating Guide (2 ${ }^{\text {nd }} E d$ ). Melbourne: The Australian Debating Federation.

Tarigan, H. Guntur. 1990. Prinsip-prinsip Dasar Metode Riset Pengajaran dan Pembelajaran Bahasa. Bandung: Angkasa.

http://www.sekolahoke.com/2010/12/9-tehnik-mengajar-speaking-technique.html. 